\title{
PERBANDINGAN EFEKTIVITAS HIPOGLIKEMIK OBAT METFORMIN PATEN DAN GENERIK BERLOGO BERDASARKAN PENURUNAN KADAR GLUKOSA DARAH MENCIT (Mus musculus) JANTAN YANG DIINDUKSI ALOKSAN
}

\author{
Aulia Wati, Rachmat Kosman, Assajadda Lizikri \\ Fakultas Farmasi Universitas Muslim Indonesia \\ Email : auliawatirusli@gmail.com
}

\begin{abstract}
Diabetes mellitus (DM) is a group of chronic diseases characterized by increased sugar levels in the blood as a result of disturbances in the body's metabolic system. Comparative studies have been conducted hypoglycemic effect of patent metformin and generic branded metformin to the diabetic male mice with the aim to determine the effect of the patent and the generic branded drug metformin drug in lowering blood glucose levels. This study used male mice were divided into three treatment groups, group I was given Na. CMC as a control, the group II was given generic branded metformin and the group III was given patent metformin. Measurement of blood glucose levels before and after induction of alloxan 120 $\mathrm{mg} / \mathrm{kgbw}$ intraperitoneally, and for 6 hours after drug administration with measurements every 90 minutes interval. The data obtained were analyzed by ANOVA. The results showed the patents metformin drug have no significantly different effects compared to the generic branded metformin drug.
\end{abstract}

Keyword : Hypoglycemic, Metformin, Patented, Generic, Mice

\section{PENDAHULUAN}

Penyakit diabetes melitus (DM) yang juga dikenal sebagai penyakit kencing manis atau penyakit gula darah adalah golongan penyakit kronis yang ditandai dengan peningkatan kadar gula (hiperglikemik) dalam darah sebagai akibat adanya gangguan sistem metabolisme dalam tubuh, dimana organ pankreas tidak mampu memproduksi hormon insulin sesuai kebutuhan tubuh.Penyakit ini membutuhkan perawatan medis berkelanjutan dan pengelolaan diri pasien dengan pendidikan dan dukungan untuk mencegah komplikasi akut dan mengurangi resiko komplikasi jangka panjang (ADA, 2013).

Data dari studi global menunjukan bahwa jumlah penderita Diabetes Melitus pada tahun 2011 telah mencapai 366 juta orang. Jika tidak ada tindakan yang dilakukan, jumlah ini diperkirakan akan meningkat menjadi 552 juta pada tahun 2030 (IDF, 2011). Menurut data WHO, Indonesia menempati urutan ke-4 terbesar dalam jumlah penderita 
Perbandingan Efektivitas Hipoglikemik Obat Metformin Paten Dan Generik Berlogo Berdasarkan Penurunan Kadar Glukosa Darah Mencit Jantan Yang Diinduksi Aloksan

Diabetes Mellitus di dunia. Pada tahun 2000 yang lalu saja, terdapat sekitar 5,6 juta penduduk Indonesia yang mengidap diabetes.Namun, pada tahun 2006 diperkirakan jumlah penderita diabetes di Indonesia meningkat tajam menjadi 14 juta orang, dimana baru 50 persen yang sadar mengidapnya dan di antara mereka baru sekitar 30 persen yang datang berobat secara teratur.

Obat paten adalah obat baru yang ditemukan berdasarkan riset dan pengembangan, diproduksi dan dipasarkan dengan nama dagang tertentu dan dilindungi hak patennya selama nominal 20 tahun.

Obat generik adalah obat yang dapat diproduksi dan dijual setelah masa paten suatu obat inovator habis. Obat Generik adalah obat yg dipasarkan berdasarkan nama bahan aktifnya. Obat patenadalah hak paten yang diberikan kepada industri farmasi pada obat baru yang ditemukannya berdasarkan riset. Industri farmasi tersebut diberi hak paten untuk memproduksi dan memasarkannya, setelah melalui berbagai tahapan uji klinis sesuai aturan yang telah ditetapkan secara internasional..

Pada tahun 1989pemerintah telah mengeluarkan kebijakan kebijakan, salah satu kebijakan tersebut adalah adanya Obat Generik Berlogo (OGB).Salah satu obat generik yang beredar dipasaran adalah obat metformin sebagai obat diabetes.Banyak masyarakat beranggapan bahwa mutu dari obat generik berlogo kurang efektif dari pada obat paten itu sendiri karena obat generik berlogo jauh lebih murah dibandingkan dengan obat paten, persepsi ini yang lazim ada dimasyarakat.

Maka berdasarkan uraian tersebut dilakukan penelitian untuk melihat perbandingan efektivitas obat metformin paten dan generik berlogo berdasarkan penurunan kadar glukosa darah mencit (Mus musculus) jantan yang diinduksi aloksan.

\section{METODE PENELITIAN}

\section{Jenis Penelitian}

Jenis penelitian yang digunakan adalah penelitian Eksperimental dengan melakukan pengujian efektivitas obat metformin paten dan generik berlogo berdasarkan penurunan kadar glukosa darah mencit (Mus musculus) yang diinduksi aloksan.

\section{Waktu dan Lokasi Penelitian}

Pelaksanaan penelitian dilakukan pada bulan Juni 2013 di Laboratorium Farmakologi Universitas Muslim Indonesia. 
Perbandingan Efektivitas Hipoglikemik Obat Metformin Paten Dan Generik Berlogo Berdasarkan Penurunan Kadar Glukosa Darah Mencit Jantan Yang Diinduksi Aloksan

\section{Alat dan Bahan digunakan}

Alat yang digunakan pada penelitian ini yaitu sonde oral, spoit 1 $\mathrm{ml}$, seperangkat alat glukometer(One touch $\left.{ }^{\circledR}\right)$, timbangan O'hauss $\left(\right.$ Camry $\left.^{\circledR}\right)$, dan timbangan analitik.

Bahan yang digunakan adalah aquadest, Natrium $\mathrm{CMC}, \mathrm{NaCl}$, obat metformin paten dan generik berlogo, dan aloksan monohydrate (Sigma Aldrich).

\section{Prosedur Penelitian}

Penyiapan Bahan

Bahan yang digunakan dalam penelitian adalah obat metformin generik berlogo dan paten.

Pembuatan Bahan Penelitian

Pembuatan larutan metformin paten

Digerus obat metformin paten dan ditimbang sebanyak 226,8 mg, dimasukkan ke dalam $100 \mathrm{ml}$ aquadest kemudian dihomogenkan.

Pembuatan larutan metformin generik berlogo

Digerus obat metformin generik berlogo dan ditimbang sebanyak 221,27 mg, dimasukkan ke dalam 100 $\mathrm{ml}$ aquadest kemudian dihomogenkan.

\section{Pembuatan suspensi aloksan}

Sebanyak 1,6 gram aloksan ditambah larutan $\mathrm{NaCl} 25 \mathrm{ml}$, dihomogenkan kemudian dicukupkan volumenya hingga $50 \mathrm{ml}$.

Pembuatan larutan Na-CMC $1 \% \mathrm{~b} / \mathrm{v}$ Sebanyak 1 g Na-CMC dimasukkan ke dalam $50 \mathrm{ml}$ air suling panas sambil diaduk dengan menggunakan pengaduk elektrik hingga terbentuk larutan yang homogen, kemudian dicukupkan volumenya hingga $100 \mathrm{ml}$.

\section{Perlakuan Terhadap Hewan Uji}

Sebelum perlakuan mencit dipuasakan selama \pm 8 jam kemudian ditimbang berat badannya dan diukur kadar glukosa darah puasa. Setelah itu diinduksi aloksan secara intraperotonial $120 \mathrm{mg} / \mathrm{kgBB}$ sebanyak $1 \mathrm{ml}$. Setelah 2 hari ukur kadar glukosa darah awal, diberikan perlakuan yang sama untuk semua kelompok.

Kelompok I diberi NaCMC sebagai kontrol, kelompok II diberi metformin paten sesuai dengan volume pemberian, kelompok III diberi metformin generik berlogo sesuai dengan volume pemberian, setelah itu dilakukan pengukuran kadar glukosa darah pada waktu $60,90,180,270$, dan 360 menit dengan masing-masing interval 90 menit 
Perbandingan Efektivitas Hipoglikemik Obat Metformin Paten Dan Generik Berlogo Berdasarkan Penurunan Kadar Glukosa Darah Mencit Jantan Yang Diinduksi Aloksan

\section{HASIL PENELITIAN}

Tabel 1. Efek obat metformin paten dan generik berlogo terhadap penurunan kadar glukosa darah mencit

\begin{tabular}{|c|c|c|c|c|c|}
\hline \multirow[b]{2}{*}{ No } & \multirow[b]{2}{*}{ Perlakuan } & \multicolumn{3}{|c|}{ Kadar glukosa darah rata-rata (mg/dL) } & \multirow{2}{*}{$\begin{array}{l}\text { Penurunan kada } \\
\text { glukosa darah } \\
\text { (gm/dL) }\end{array}$} \\
\hline & & $\begin{array}{l}\text { Jumlah } \\
\text { mencit }\end{array}$ & Awal & $\begin{array}{c}\text { Rata-rata selama } \\
5 \text { jam }\end{array}$ & \\
\hline 1 & $\mathrm{Na}$ CMC $1 \%$ & 3 & 113 & 104.47 & 234.53 \\
\hline 2 & Metformin paten & 3 & 140,67 & 76.4 & 345.60 \\
\hline 3 & $\begin{array}{l}\text { Metformin } \\
\text { generik berlogo }\end{array}$ & 3 & 153,33 & 110.87 & 349.13 \\
\hline
\end{tabular}

Tabel 2. Hasil pengamatan pengaruh $\mathrm{Na} \mathrm{CMC}$, Metfromin paten, dan generik berlogo terhadap penurunan kadar glukosa darah mencit.

\begin{tabular}{|c|c|c|c|c|c|c|c|c|}
\hline \multirow[b]{2}{*}{ Perlakuan } & \multirow[b]{2}{*}{ Mencit } & \multicolumn{6}{|c|}{ Kadar Glukosa Darah (mg/dL) } & \multirow[b]{2}{*}{ Total A } \\
\hline & & Awal & $\begin{array}{l}\text { Menit } \\
60\end{array}$ & $\begin{array}{c}\text { Menit } \\
90\end{array}$ & $\begin{array}{c}\text { Menit } \\
180\end{array}$ & $\begin{array}{c}\text { Menit } \\
270\end{array}$ & $\begin{array}{c}\text { Menit } \\
360\end{array}$ & \\
\hline \multirow{5}{*}{ Na.CMC } & $\mathrm{I}$ & 112 & 103 & 106 & 88 & 90 & 92 & 591 \\
\hline & II & 105 & 98 & 102 & 95 & 95 & 98 & 593 \\
\hline & III & 122 & 130 & 118 & 116 & 118 & 118 & 722 \\
\hline & $\Sigma x$ & 339 & 331 & 326 & 299 & 303 & 308 & 1906 \\
\hline & $\mathrm{x}$ & 113 & 110.33 & 108.67 & 99.67 & 101.00 & 102.67 & 635.33 \\
\hline \multirow{5}{*}{$\begin{array}{l}\text { Metformin } \\
\text { Paten }\end{array}$} & 1 & 149 & 109 & 106 & 104 & 101 & 95 & 664 \\
\hline & II & 130 & 120 & 72 & 49 & 39 & 38 & 448 \\
\hline & III & 143 & 103 & 85 & 46 & 43 & 36 & 456 \\
\hline & $\Sigma x$ & 422 & 332 & 263 & 199 & 183 & 169 & 1568 \\
\hline & $x$ & 140.67 & 110.67 & 87.67 & 66.33 & 61.00 & 56.33 & 522.67 \\
\hline \multirow{5}{*}{$\begin{array}{l}\text { Metformin } \\
\text { generik } \\
\text { berlogo }\end{array}$} & $\mathrm{I}$ & 153 & 143 & 129 & 113 & 103 & 101 & 742 \\
\hline & II & 155 & 137 & 132 & 119 & 108 & 87 & 738 \\
\hline & III & 152 & 124 & 117 & 112 & 78 & 60 & 643 \\
\hline & $\Sigma x$ & 460 & 404 & 378 & 344 & 289 & 248 & 2123 \\
\hline & $x$ & 153.33 & 134.67 & 126.00 & 114.67 & 96.33 & 82.67 & 707.67 \\
\hline \multicolumn{2}{|c|}{ Total B } & 2849.00 & 2489.67 & 2256.33 & 1964.67 & 1808.33 & 1691.67 & 13059.67 \\
\hline
\end{tabular}

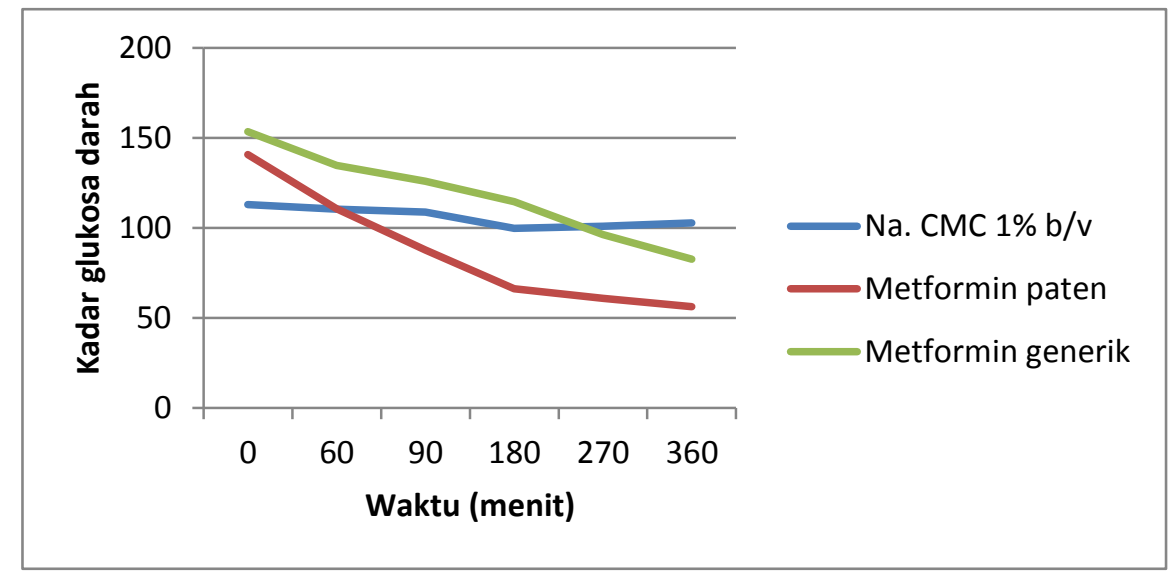

Gambar 1. Grafik pengaruh Na. CMC, metformin paten, metformin generik berlogo terhadap penurunan kadar glukosa darah mencit 
Perbandingan Efektivitas Hipoglikemik Obat Metformin Paten Dan Generik Berlogo Berdasarkan Penurunan Kadar Glukosa Darah Mencit Jantan Yang Diinduksi Aloksan

PEMBAHASAN

Penyakit Diabetes Melitus (DM) yang juga dikenal sebagai penyakit kencing manis atau penyakit gula darah adalah golongan penyakit kronis yang ditandai dengan peningkatan kadar gula (hiperglikemik) dalam darah sebagai akibat adanya gangguan sistem metabolisme dalam tubuh, dimana organ pankreas tidak mampu memproduksi hormon insulin sesuai kebutuhan tubuh.

Penelitian dilakukan untuk melihat dan menentukan perbedaan efektivitas antara obat mrtformin paten dan generik berlogo dalam menurunkan kadar glukosa darah mencit (Mus musculus) jantan yang telah diinduksi aloksan.

Sebelum melakukan penelitian terlebih dahulu mencit dipuasakan \pm 8 jam dengan maksud untuk meminimalkan pengaruh makanan pada pengukuran kadar glukosa darah. Walaupun demikian, faktor variasi biologis dari hewan coba tidak dapat dihilangkan sehingga faktor ini relative dapat mempengaruhi hasil, oleh karena itu terdapat perbedaan konsentrasi darah awal untuk tiap hewan coba.

Pemberian larutan aloksan pada mencit dilakukan $2 \times 24$ jam sebelum perlakuan dengan tujuan untuk menaikkan kadar glukosa darah mencit dengan merusak sel-sel $\beta$ pannkreas. Aloksan bereaksi dengan merusak substansi esensial didalam sel beta pankreas sehingga menyebabkan berkurangnya granula granula pembawa insulin di dalam sel beta pankreas.Aloksanmeningkatkan pelepasan insulin dan protein dari sel beta pankreas tetapitidak berpengaruh pada sekresi glukagon.

Setelah dilakukan induksi selanjutnya dilakukan pengujian obat metformin. Metformin bekerja menurunkan produksi glukosa di hepar dan meningkatkan sensitivitas jaringan otot dan adiposa terhadap insulin, menurunkan glukosa darah melalui pengaruhnya terhadap kerja insulin pada tingkat selular, distal reseptor insulin dan menurunkan produksi glukosa hati, meningkatkan pemakaian glukosa oleh sel usus sehingga menurunkan glukosa darah dan juga diduga menghambat absorpsi glukosa di usus sesudah asupan makan.

Pada pengukuran kadar glukosa menggunakan alat glukometer dimana mekanisme kerjanya yaitu tetesan darah yang mengandung glukosa akan bereaksi dengan glukosa oksidase yang terkandung dalam strip dan akan merubah warna strip, warna yang dihasilkan berbeda-beda. 
Perbandingan Efektivitas Hipoglikemik Obat Metformin Paten Dan Generik Berlogo Berdasarkan Penurunan Kadar Glukosa Darah Mencit Jantan Yang Diinduksi Aloksan

Intensitasnya warnanya sesuai dengan jumlah glukosa yang terdapat pada darah dan diukur secara fotometik.

Setelah dilakukan pengukuran kadar glukosa darah selama 6 jam, diperoleh nilai rata-rata penurunan glukosa (tabel 2). Hasil yang diperoleh selanjutnya dianalisis dengan pengujian Wilcoxon test untuk mengukur perbedaan kadar glukosa sebelum dan setelah perlakuan. Hasil analisisnya menunjukkan perbedaan nyata dengan nilai signifikansi 0,008 $(p<0,005)$, artinya induksi alloksan berhasil karena terjadi perbedaan antara kadar glukosa darah sebelum induksi dan setelah induksi.

Data kemudian dianalisis kembali menggunakan ANOVA untuk melihat perbedaan antar kelompok sehingga diperoleh nilai signifikansi sebesar $0,09 \quad(p<0,005)$, artinya terdapat perbedaan nyata antara tiap kelompok perlakuan. Sehingga analisis dilanjutkan dengan Post Hoc Tests LSD untuk melihat signifikansi antar kelompok perlakuan.

Dari analisis Post Hoc TestsLSD, kelompok $\mathrm{Na}$. CMC menunjukkan perbedaan nyata (signifikan) terhadap metformin berlogo dan paten dengan nilai 0,011 dan 0,004. Artinya, $\mathrm{Na}$. CMC memiliki efek yang berbeda nyata dengan efek metformin berlogo dan paten. Kelompok metformin berlogo menunjukkan nilai yang tidak signifikan terhadap metformin paten dengan nilai 0.439 . Artinya kelompok metformin generik berlogo memiliki efek yang hampir sama dengan efek metformin paten dalam penurunan kadar glukosa darah mencit.

Dari gambar 1 untuk grafik penurunan kadar glukosa darah menunjukkan metformin paten memberikan penurunan kadar glukosa darah yang lebih baik dibandingkan dengan metformin generik berlogo namun dari hasil analisis statistik menununjukkan bahwa obat metformin generik berlogo memiliki efektivitas yang sama dengan metformin paten dalam penurunan kadar glukosa darah.

\section{KESIMPULAN}

Berdasarkan hasil penelitian secara statistik dapat disimpulkan bahwa obat metformin paten dan generik berlogo mempunyai efektifitas yang sama dalam penurunan kadar glukosa darah.

\section{DAFTAR PUSTAKA}

Anonim, 2008.Referensi Kesehatan Diabetes Melitus (Internet).http://creasoft wordpress. com/dibetes mellitus (diakses 2011).

Anonim, 2009. Defenisi obat yang ada di Indonesia (Internet). 
Perbandingan Efektivitas Hipoglikemik Obat Metformin Paten Dan Generik Berlogo Berdasarkan Penurunan Kadar Glukosa Darah Mencit Jantan Yang Diinduksi Aloksan

http://www.stopobatpalsu.com/ index.php?modul=bertindak\&c at=BerObat (diakses 2011).

Anonim, 2011.Mengenal Lebih Dekat Obat Generik berlogo (Internet).http://www.dexamedica.com/printview.php?cid $=1 \& \mathrm{id}=291$ (diakses 2011).

Arora, Anjali, 2007. 5 Langkah Mencegah dan Mengobati Diabetes. PT. Bhuana IImu Populer : Jakarta.

American Diabetes Association. 2013. Standards ofMedical Care in Diabetes-2013. Diabetes Care, Volume 36, Supplement 1 (Internet).http://www.ncbi.nlm. nih.gov/pmc/articles /PMC357269/.

(Diakses Januari 2014).

Bustan, M.N, 2007. Epidemiologi Penyakit Tidak Menular. Rineka Cipta. Jakarta.

DEPKES, 2005.Pharmaceutical Care Untuk Penyakit Diabetes Mellitus:Jakarta.

Gunawan, Gan, Sulistia, dkk, 2007.Farmakologi dan Terapi Edisi 5. Departemen Farmakologi dan Terapeutik, Fakultas Kedokteran, UI : Jakarta.

International Diabetes Federation. 2011. One Adult In Ten Will Have Diabetes By 2030. [http://www.idf.org/mediaevents/press- releases/2011/diabetes-atlas8th-edition] [Diunduh pada 18 Januari 2012 pukul 17.45 WIB]

Lenzen S, 2008. The mechanism of alloxan and streptozotocin induced

diabetes,(Internet)http://www.n cbi.nlm.nih.gov/pubmed/18087 688 ?ordinalpos $=1$ \&itool=Entre zSystem2.PEntrez.Pubmed.Pu bmed ResultsPanel.Pubmed DiscoveryPanel.Pubmed Disc overy RA\&linkpos=4\&log $\$=$ rel atedreviews\&logdbfrom $=$ pub (diakses 2011).

Sudarmoko, Arief, 2010. Tetap Tersenyum Melawan Diabetes. Atma Media Press: Yogyakarta.

Suharmiati, 2003, Pengujian bioaktifitas anti diabetes melitus tumbuhan obat, Cermin Dunia Kedokteran.(Internet).http://ww w.kalbe.co.id/files/cdk/06 Pen gujianBioaktivitasAntiDiabetes. pdf (diakses 2011).

Szkudelski T, 2008. The mechanism of alloxan and streptozotocin action in $B$ cells of the rat pancreas (Internet) www.ncbi.nlm.nih.gov/pubmed 11829314 (diakses 2011).

Sunaryati,S.S, 2011. 14 Penyakit Paling Sering Menyerang dan Sangat Mematikan. Cetak Pertama. FlashBook: Jogjakarta. 